\title{
TINJAUAN YURIDIS PERANTARA TINDAK PIDANA NARKOTIKA MENURUT UNDANG-UNDANG NOMOR 35 TAHUN 2009
}

\author{
Oleh \\ Suisno \\ Dosen Fakultas HukumUniversitas Islam Lamongan
}

\begin{abstract}
Abstrak
Salah satu persoalan yang sering muncul kepermukaan dalam kehidupan masyarakat ialah tentang kejahatan pada umumnya, seperti pada saat ini sering kita jumpai kenakalan berupa penyalahgunaan narkotika. Di dalam pasal 1 ayat 1 Undang-Undang Nomor 35 Tahun 2009 Tentang Narkotika disebutkan pengertian narkotika, yaitu zat atau obat yang berasal dari tanaman, baik sintesis maupun semisintesis. Rumusan masalah dalam penelitian ini meliputi pengaturan perantara narkotika dan sanksi perantra narkotika. Manfaat dari penelitan ini adalah mencegah penyalahgunaan narkotika, menambah wawasan penulis mengenai tindak pidana narkotika. Metode penelitian yang digunakan adalah yuridis normatif dengan pendekatan masalah yaitu pendekatan perundang undangan. Ketentuan perantara narkotika hanya diatur dalam Undang-undang Nomor 35 Tahun 2009 tentang Narkotika. Setiap orang yang tanpa hak atau melawan hukum menawarkan untuk dijual, menjual, membeli, menerima, menjadi perantara dalam jual beli, menukar, atau menyerahkan Narkotika Golongan I, Golongan II, Golongan III dipidana penjara atau denda sesuai dengan pasal 114, 119, 124, 129.Adapun sanksi sanki bagi penyalahgunaan narkotika juga di atur dalam Undang Undang narkotika nomor 35 tahun 2009, dan untuk sanksi perantara narkotika pun tetap diatur dalam Undang Undang narkotika nomor 35 tahun 2009 yang tercantum dalam pasal 114, 119, 124, 129 yang menjatuhkan hukuman pidana paling singkat 3 (tiga) tahun atau denda 600.000 .000 (enam ratus juta rupiah) dan pidana paling lama 20 (dua puluh) tahun atau denda 10.000.000.000 (sepuluh miliar rupiah).Dari pembahasan dapat disimpulkan bahwa ketentuan hukum dan sanksi hukum bagi perantra narkotika tidak diatur secara khusus oleh Undang Undang narkotika, saran ketentuan hukum perantara narkotika seharusnya dibuat lebih jelas lagi atau dibentuk Undang Undang yang khusus agar tidak di samakan dengan pengedar narkotik, karena banyak pelaku yang merasa terjebak menjadi perantara narkotika.
\end{abstract}

Kata Kunci: Perantara, Tindak Pidana ,Narkotika

\section{A. Pendahuluan}

\section{Latar Belakang}

Negara Indonesia adalah Negara hukum, hal tersebut tertuang didalam penjelasan Undang-Undang Dasar 1945 yang menyatakan bahwa: "Negara Indonesia berdasarkan atas hukum dan tidak berdasarkan atas kekuasaan belaka" Hukum merupakan suatu kaidah atau peraturan yang mengatur masyarakat. Segala tingkah laku dan perbuatan warga negaranya harus berdasarkan atas hukum. Oleh karena itu, bagi Indonesia yang sebagai Negara hukum, wajib untuk menjalankan fungsi hukum dengan konsisten sebagai sarana penegak keadilan. Perkembangan jaman yang semakin maju, tentu kejahatanya pun lebih berkembang dan terorganisir Salah satu persoalan yang sering muncul ke permukaan dalam kehidupan masyarakat ialah tentang kejahatan pada umumnya, seperti pada saat ini sering kita jumpai kenakalan berupa penyalahgunaan narkotika. Di dalam pasal 1 ayat 1 Undang-Undang 
Nomor 35 Tahun 2009 Tentang

Narkotika disebutkan pengertian narkotika, yaitu zat atau obat yang berasal dari tanaman, baik sintesis maupun semisintesis,yang dapat menyebabkan penurunan atau perubahan kesadaran, hilangnya rasa, mengurangi sampai menghilangkan rasa nyeri, dan dapat menimbulkan ketergantungan, yang dibedakan kedalam golongan-golongan sebagaimana terlampir dalam Undangundang. Narkotika sejatinya dimanfaatkan oleh dunia medis untuk menggunakan narkotika yang diberikan kepada pasien tertentu yang membutuhkan terutama pada saat pelaksanaan operasi agar pasien tidak merasakan sakit ketika dokter atau pihak medis melaksanakan tugasnya. Narkotika juga dibutuhkan untuk kepentingan pendidikan, pelatihan, dan keterampilan yang dilaksanakan oleh Instansi Pemerintah yang tugas dan fungsinya melakukan pengawasan, penyelidikan, penyidikan, dan pemberantasan peredaran gelap narkotika misalnya saja Badan Narkotika Nasional (BNN) serta Bea dan Cukai. Disamping manfaatnya dalam dunia pengobatan, narkotika juga dapat merugikan apabila disalahgunakan oleh pemakainya dan dapat membahayakan bagi kehidupan masyarakat terutama para pemuda yang merupakan generasi penerus bangsa dan negara Indonesia. Ketentuan Undangundang Nomor 35 Tahun 2009 tentang Narkotika sudah diatur tentang sanksi pidana yang akan diberikan kepada yang melanggarnya. Sanksi yang diberikan kepada pelaku tindak pidana sebenarnya cukup berat, di samping dikenakan pidana penjara dan pidana denda, juga yang paling utama adalah dikenakannya batasan minimum dan maksimum ancaman pidana, baik pidana penjara maupun pidana denda serta adanya ancaman pidana mati menunjukkan beratnya sanksi pidana yang diatur dalam Undang-Undang Narkotika ini. Pasal 111 sampai dengan Pasal 148 Undang-Undang Nomor 35 Tahun 2009 tentang Narkotika menentukan bahwa pidana yang dapat dijatuhkan berupa :

1. Pidana mati (Pasal 116 ayat (2), Pasal 119 ayat (2) dan Pasal 121 ayat (2)).

2. Pidana penjara (Pasal 111 sampai Pasal 148).

3. Pidana kurungan (Pasal 128).

4. Pidana denda (Pasal 111 sampai Pasal 148).

5. Pidana juga dapat dijatuhkan pada korporasi yakni berupa pencabutan izin usaha; dan/atau. pencabutan status badan hukum (Pasal 130).

6. Rehabilitasi Medis dan Sosial (Pasal 54 sampai Pasal 59 Pasal 103 ayat (1) dan ayat (2) dan Pasal 127).

Berdasarkan uraian tersebut di atas, penulis tertarik untuk meneliti dan mengkaji lebih mendalam

\section{Rumusan Masalah}

Dilihat dari latar belakang permasalahan di atas,maka penulis dapat merumuskan masalah sebagai berikut :

1. Bagaimana ketentuan yang mengatur tentang perantara tindak pidana narkotika menurut undang undang nomor 35 tahun 2009 ?

2. Bagaimana sanksi terhadap perantara tindak pidana narkoba menurut undang - undang nomor 35 tahun 2009 ?

\section{Tujuan Penulisan}

Berdasarkan rumusan masalah diatas, maka penulisan penelitian ini bertujuan untuk:

1. Untuk menganalisa ketentuana yang menyangkut tentang perantara tindak pidana narkotika. 
2. Untuk mengetahui sanksi terhadap perantara tindak pidana narkotika.

\section{B. Metode Penelitian}

\section{Tipe penelitian}

Yang dipergunakan dalam penyusunan skripsi ini adalah Yuridis Normatif, artinya permasalahan yang diangkat, dibahas dan diuraikan dalam penelitian ini difokuskan dengan menerapkan kaidah-kaidah atau normanorma dalam hukum positif. Tipe penelitian yuridis normatif dilakukan dengan mengkaji berbagai macam aturan hukum yang bersifat formal seperti Undang-Undang, literaturliteratur yang bersifat konsep teoritis yang kemudian dihubungkan dengan permasalahan yang menjadi pokok pembahasan. $^{48)}$

\section{Pendekatan Masalah}

Pendekatan yang digunakan oleh penulis yaitu pendekatan perundangundangan (statute approach). Pendekatan perundang-undangan (Statute Approach), adalah pendekatan yang dilakukan dengan menelaah semua undang undang dan regulasi yang bersangkut paut dengan isu hukum yang sedang ditangani. Hasil dari telaah tersebut merupakan suatu argumen untuk memecahkan isu yang dihadapi

${ }^{49) .}$ Selain itu digunakan pendektan lainya guna mempermudah analisa ilmiah yang dibutuhkan dalam permasalahan ini.

\section{Bahan Hukum}

Bahan hukum merupakan sarana dari suatu penulisan yang digunakan untuk memecahkan permasalahan yang

\footnotetext{
${ }^{48)}$ Peter Mahmud Marzuki, 2010, Penelitian Hukum, Kencana Prenada Media Group, Jakarta, hlm.194

49) Ibid, hlm.93
}

ada sekaligus memberikan preskripsi mengenai apa yang seharusnya, bahan hukum tersebut meliputi :

Bahan hukum primer adalah bahan hukum yang bersifat autoritatifyang artinya mengikat dan mempunyai otoritas. Bahan-bahan hukum primer terdiri dari perundangundangan,catatan-catatan resmi atau risalah dalam pembuatan perundangundangan dan putusan-putusan hakim. Bahan hukum primer yang akan digunakan dalam penulisan skripsi ini adalah :

1. Undang-Undang Dasar Republik Indonesia 1945.

2. Kitab Undang-Undang Hukum Pidana

3. Undang-Undang Nomor 35 Tahun 2009 tentang Narkotika .

4. PutusanPengadilan Negeri Jakarta Utara Nomor 1347/pid.sus/2015/PN.JKT. UTR

Bahan hukum sekunder adalah bahan-bahan yang erat hubungannya dengan bahan hukum primer dan dapat membantu menganalisis serta memahami bahan hukum primer. Bahan hukum sekunder diperoleh dari hasil karya tulis ilmiah para sarjana dan ahli yang berupa literatur, majalah, jurnal, sehingga dapat mendukung, membantu, melengkapi, dan membahas masalahmasalah yang timbul dalam skripsi ini.

\section{Prosedur Pengumpulan Bahan Hukum}

Dalam penelitian ini yang digunakan adalah penelitian hukum normatif atau penelitian hukum kepustakaan, maka dalam pengumpulan bahan hukum penulis menggunakan bahan hukum primer maupun bahan hukum sekunder untuk membahas permasalah dalam penelitian ini. Dengan begitu akan mempermudah dalam menyelesaikan permasalahan 
yang ada dan dapat mempercepat proses penulisan penelitian ini.

\section{Pengolahan dan Analisis Bahan Hukum}

Analisis yang digunakan adalah analisis deskriptif, yang dimulai dengan mengelompokan data yang dilakukan secara induksi sehingga memberikan hasil secara sempurna, untuk memperoleh informasi yang akurat dengan begitu penelitian dapat lebih terfokus pada masalah yang spesifik. Selain itu dapat mempermudahkan penulis dalam menganalisa data yang sudah lengkap dan yang telah dikumpulkan.Hasil Penelitian dan Pembahsan

\section{Ketentuan Yang Mengatur Tentang Perantara Tindak Pidana Narkotika Menurut Undang-Undang Nomor 35 Tahun 2009}

Tindak pidana merupakan terjemahan kata strafbaarfeit dalam bahasa Belanda. Dilihat dari sudut pandang harfiahnya, strafbaarfeit itu terdiri dari kata feit yang dalam bahasa belanda berarti sebagian dari suatu kenyataan atau eengedeelte van de werkelijkheid, sedangkan strafbaar berarti dapat dihukum .Secara harfiah kata strafbaarfeit dapat diterjemahkan sebagai sebagian dari suatu kenyataan yang dapat dihukum. ${ }^{50)}$.

Dari kata strafbaarfeit kemudian diterjemahkan dalam berbagai bahasa Indonesia oleh para sarjana-sarjana di Indonesia, antara lain: tindak pidana, delik, dan perbuatan pidana.

Tindak pidana hanyalah salah satu terjemahan dari istilah dalam bahasa belanda yaitu strafbaarfeit. Sebetulnya

\footnotetext{
${ }^{50)}$ P.A.F. Lamintang, 1997, Dasar-Dasar Hukum Pidana Indonesia, Citra Aditya Bakti, Bandung, hlm. 181.
}

istilah tersebut bersifat eliptis (kependekan dari) sebagian kalimat yang dihilangkan. Kalimat sesungguhnya adalah feit tarzaake van het welke een person stafbaar is (perbuatan oleh karena mana seseorang dapat dipidana). Dengan demikian, berdasarkan pengertian strafbaafeit diatas maka para pakar hukum pidana menerjemahkan strafbaafeit itu berbeda-beda, ada yang menerjemahkan sebagai peristiwa pidana, perbuatan pidana, perbuatan boleh dihukum, dan ada juga dengan singkatan menyebutnya sebagai delik. Hukum pidana yang beraliran anglo saxon (Anglo Amerika) dengan system common law mempergunakan istilah criminal act, offense, commited, atau ada pula yang menyebut criminal conduct. ${ }^{51)}$ Dengan demikian tindak pidana merupakan perbuatan yang dilarang oleh hukum dan diancam dengan pidana

Setelah mengetahui definisi dan pengertian yang lebih mendalam dari tindak pidana itu sendiri, maka di dalam tindak pidana tersebut terdapat unsurunsur tindak pidan, yaitu

a. Unsur Obyektif Unsur yang terdapat di luar si pelaku. Unsur-Unsur yang ada hubunganya dengan keadaan, yaitu dalam keadaan-keadaan di mana tindakan-tindakan si pelaku itu harus dilakukan

b. Unsur Subyektif Unsur yang terdapat atau melekat pada diri si pelaku atau yang dihubungkan dengan diri si pelaku dan termasuk didalamanya segala sesuatu yang terkandung di dalam hatinya

Subjek Tindak Pidana

51) Ibid, hlm.181 
Rumusan tindak pidana didalam buku kedua dan ketiga KUHP biasanya dimulai dengan kata barangsiapa. Ini mengandung arti bahwa yang dapat melakukan tindak pidana atau subjek tindak pidana pada umumnya adalah manusia.

Memang pandangan klasik berpendapat bahwa subjek tindak pidana adalah orang pribadi, meskipun ia berkedudukan sebagai pengurus atau komisaris suatu badan hukum. Namun , menurut perkembangan zaman subjek tindak pidan dirasakan perlu diperluas termasuk bandan hukum.

Jenis Tindak Pidana

KUHP telah mengklasifikasikan tindak pidana atau delik ke dalam dua atau kelompok besar yaitu dalam Buku Kedua dan Ketiga masing-masing menjadi kelompok kejahatan dan pelanggaran. Kemudian bab-babnya dikelompokan menurut sasaran yang hendak dilindungi oleh KUHP terhadap tindak pidana tersebut.

1. Kejahatan dan pelanggaran

2. Delik formil dan delik materiil

3. Delik commisionis, delik ommisionis, dan delik commisionis per ommisionen commiss.

4. Delik dolus dan culpa

5. Delik biasa dan delik aduan

Disamping tindak pidana yang tercantum dalam KUHP adabeberapa macam tindak pidana yang pengaturannya berada diluar KUHPatau disebut"tindak pidana khusus".Adapun jenis-jenis tindak pidana diluar KUHP antaralain :Tindak Pidana Imigrasi, Tindak Pidana Ekonomi, Tindak Pidana Narkotika.

Undang-Undang Nomor 35 Tahun 2009 tentang Narkotika adalah merupakan salah satu bentuk Undang-undang yang mengatur tindak pidana di luar KUHP. UndangUndang Nomor 35 Tahun 2009 tentang Narkotika merupakan ketentuan khusus dari ketentuan umum (KUHP) sebagai perwujudan dari asas lex specialis derogat lex generalis. Oleh karena itu terhadap kejadian yang menyangkut tindak pidana narkotika harus diterapkan ketentuan-ketentuan tindak pidana dalam undang-undang tersebut, kecuali hal-hal yang belum diatur di dalamnya.

Tindak Pidan Narkotika

Pengertian tindak pidana narkotika tidak kita ketemukan dalam UndangUndang Nomor 35 Tahun 2009 tentang Narkotika. Dalam ketentuan Undangundang Nomor 35 Tahun 2009 tentang Narkotika menentukan beberapa tindak pidana narkotika, yakni dalam Pasal 111 sampai Pasal 148 Undang-undang Nomor 35 Tahun 2009 tentang Narkotika. Dalam Undang-undang Nomor 35 Tahun 2009 tentang Narkotika ditentukan bahwa pidana yang dapat dijatuhkan berupa pidana mati, pidana penjara, pidana kurungan dan pidana denda. Pidana juga dapat dijatuhkan pada korporasi yakni berupa pencabutan izin usaha; dan/atau pencabutan status badan hukum.

Demikian halnya dengan pengertian tindak pidana narkotika juga tidak disebutkan dalam UndangUndang Nomor 22 Tahun 1997 tentang Narkotika dan Undang-Undang Nomor 5 Tahun 1997 tentang psikotropika, maupun Undang-undang yang berlaku sebelumnya, seperti stb, 1927. No.278 jo No.536 tentang Ver Doovende Middelen Ordonantie dan Undangundang Nomor 9 tahun 1976 tentang Narkotika. Undang-undang narkotika dan psikotropika tidak membahas mengenai pengertian tindak pidana narkotika dan psikotropika, namun atas dasar pengertian dan penjelasan tentang tindak pidana di atas, akan membantu dalam memberikan pengertian tentang tindak pidana narkotika dan psikotropika yang tentu saja tetap mengacu pada ketentuan-ketentuan 
yang terdapat dalam Undang-undang Nomor 5 Tahun 1997 tentang Psikotropika. Dalam ketentuan Pasal 1 angka 15 Undang-undang Nomor 35 Tahun 2009 disebutkan bahwa : Penyalah Guna adalah orang yang menggunakan Narkotika tanpa hak atau melawan hukum.

Menurut Veronica Colondam, penyalahgunaan mengatakan narkoba adalah penyalahgunaan terhadap berbagai obat-obatan yang masuk dalam daftar hitam yakni daftar obat yang masuk Undang-Undang Narkotika dan Psikotropika. Ia pun mengatakan kembali, bahwa penyalahgunaan narkoba adalah penyalahgunaan yang berkonsekuensi pada hukum, hal ini lantaran penyalahgunaan akan memberikan dampak pada perubahan metal, kecanduan, dan prilaku.

Sedangkan menurut Martaniah Penyalahgunaan NAPZA termasuk narkoba adalah penyalahgunaan yang disebabkan oleh komponen psikologis, seperti politik, hukum, dan sosial. Kebijakan penanggulangan tindak pidana penyalahgunaan narkotika tidak bisa lepas dari tujuan Negara untuk melindungi segenap bangsa Indonesia dan untuk memajukan kesejahteraan umum berdasarkan Pancasila dan Undang Undang Dasar 1945. Sebagai warga Negara berkewajiban untuk memberikan perhatian pelayanan pendidikan melalui pengembangan ilmu pengetahuan. Disisi lain perhatian pemerintah terhadap keamanan dan ketertiban masyarakat khususnya yang berdampak dari gangguan dan perbuatan pelaku tindak pidana narkotika. Pidana itu berkaitan erat dengan hukum pidana dan hukum pidana merupakan suatu bagian dari tata hukum, karena sifatnya yang mengandung sanksi. Oleh karena itu, seorang yang dijatuhi pidana ialah orang yang bersalah melanggar suatu peraturan hukum pidana atau melakukan tindak pidana atau tindak kejahatan.

\section{Perantara Narkotika}

Perantra narkotika bisa di sebut juga calo narkotika yang berdasarkan Kmaus Besar Bahasa Indonesia calo memiliki arti adalah orang yang menjadi perantara dan memberikan jasanya untuk mengurus sesuatu berdasarkan upah. Di dalam UndangUndang Nomor 35 Tahun 2009 Tentang Narkotika terdapat ketentuan yang mengatur pidana bagi orang yang menjadi perantara. Sanki-sanki tersebut berbeda-beda bergantung pada jenis golongan narkotika, beratnya, dan bentuknya (apakah masih dalam bentuk tanaman atau narkotika siap pakai)

\section{Pidana}

Pidana mempunyai pengertian yang luas karena pengertian pidana merupakan istilah umum, sehingga perlu adanya pernyataan khusus mengenai apa arti pidana.Pidana berasal dari kata straf (Belanda), yang pada dasarnya dapat dikatakan sebagai suatu penderitaan (nestapa) yang sengaja dikena-kan/dijatuhkan kepada seseorang yang telah terbukti bersalah melakukan suatu tindak pidana. ${ }^{52)}$ Sebagaimana yang dikemukakan oleh Muladi dan Barda Nawawi Arief bahwa :
Istilah "hukuman"
merupakan istilah umum dan konvensional, dapatmempunyai arti yang luas dan berubah-ubah karena istilah tersebut dapat berkonotasi dengan bidang yang cukup luas seperti di bidang pendidikan, moral,

\footnotetext{
52) Alfi Fahmi, 2002, Sistem Pidana di Indonesia,
} PT. Akbar Pressindo, Surabaya, hlm.1 
agama dan sebagainya. Oleh

karena itu, pidanalebih khusus perlu ada pembatasan pengertian atau makna sentral yang dapat menunjukkan ciriciri atau sifat-sifatnya yang khas. ${ }^{53)}$

\section{Satochid \\ Kartanegara}

menyebutkan bahwa :

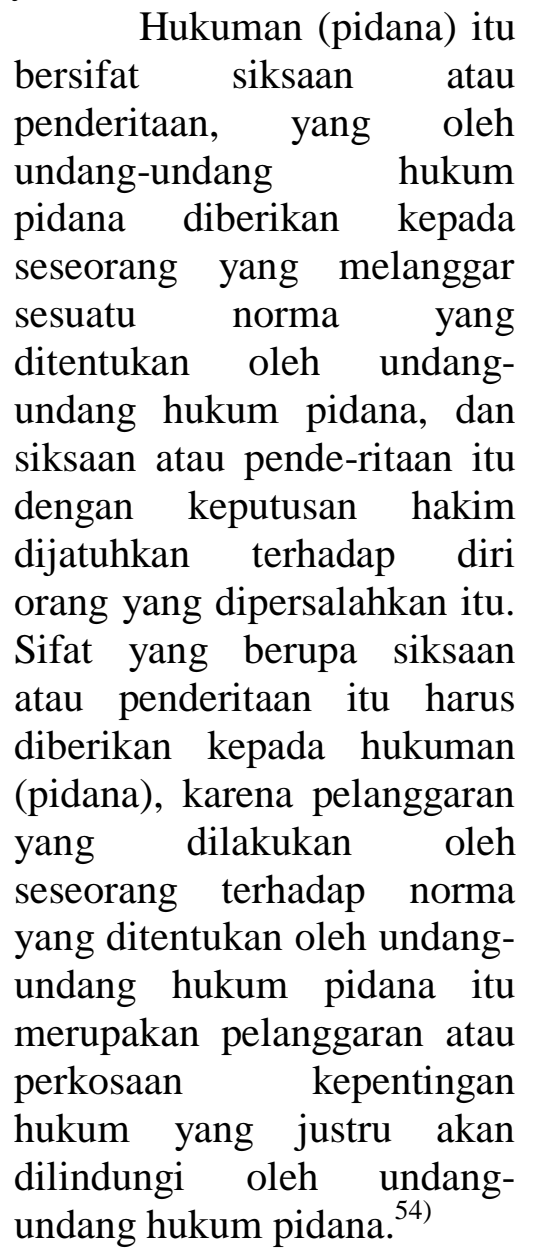

Ketentuan yang mengatur tindak pidana narkotika pertama diatur dalam Undang-Undang Nomor 22 tahun 1997 pasal 78, 79, 80,81,82, 86, dan 87 karena seiring berkembangnya zaman dan semakin banyak penyalahgunaan narkotika di indonesia Undang Undang

\footnotetext{
53) Muladi \& Barda Nawai Arief, 2005 Teori-Teori dan Kebijaksanaan Pidana, Bandung, PT. Alumni, hlm.2

54) Satochid Kartanegara, 1954-1955, Kumpulan Catatan Kuliah Hukum Pidana II, disusun oleh Mahasiswa PTIK Angkatan V, hlm. 275-276
}

nomor 22 tahun 1997 di gantikan oleh Undang Undang nomor 35 tahun 2009 perubahan itu sesuai dengan pasal 153 tahun 2009 yang berbunyi sebagai berikut:

pasal 153:

Dengan berlakunya undangundang ini:

a) Undang-Undang nomor 22 tahun 1997 tentang narkotika (Lembaran Negara Republik Indonesia Tahun 1997 Nomor 67, Tambahan Lembaga Negara Republik Indonesia Nomor 3689); dan

b) Lampiran mengenai jenis pisikotropika golongan I dan golongan II sebagaimana tercantum dalam Lampiran Undang-Undang Nomor 5 Tahun 1997 tentang Pisikotropika (Lembaga Negara Republik Indonesia Tahun 1997 Nomor 10, Tambahan Lembaga Negara Republik Indonesia 3671) yang telah dipindahkan menjadi Narkotika Golongan I menurut Undang-Undang ini, dicabut dan dinyatakan tidak berlaku.

Dari penjelasan pasal 153 UndangUndang Nomor 35 Tahun 2009 tersebut, dapat diketahui bahwa Undang-Undang Nomor 35 Tahun 2009 mencabut Undang-undang Nomor 22 Tahun 1997. Sedangkan ketentuan yang mengatur sebagai perantara narkotika itu sendiri hanya di atur dalam Undang Undang nomor 35 tahun 2009 dalam pasal 114, 119, 124, 129.

\section{SANKSI HUKUM TERHADAP PERANTARA TINDAK PIDANA NARKOTIKA}

Pengertian Sanksi

Hukum dan sanksi dapat diibaratkan dua sisi uang yang satu saling melengkapi. Hukum tanpa sanksi sangat sulit melakukan penegakan hukum, bahkan dapat dikatakan bahwa 
norma sosial tanpa sanksi hanyalah moral, bukan hukum, sebaliknya sanksi tanpa hukum dalam arti kaidah akan terjadi kesewenang-wenangan penguasa.Sanksi selalu terkait dengan norma hukum atau kaidah hukum dengan norma-norma lainnya, misalnya norma kesusilaan, norma agama atau kepercayaan, norma sopan santun (Zainuddin, 2008 : 43). Dengan sanksilah maka dapat dibedakan antara norma hukum dengan norma lainnya. Arti sanksi sendiri adalah Suatu langkah hukuman yang dijatuhkan oleh negara atau kelompok tertentu karena terjadi pelanggaran yang dilakukan oleh seseorang atau kelompok.

Sanksi Terhadap Tindak Pidana Narkotika

Dalam Undang Undang nomor 35 tahun 2009 tentang Narkotika menjelaskan semua hal yg berkaitan dengan narkotika baik itu pengertian narkotika, dasar, asas, tujuan, ruang lingkup, peredaran sampai dengan sanksi pidana bagi yang melanggarnya. Sanksi sanksi tersebut meliputi

Menanam, Memelihara, Memiliki, Menyimpan, Menguasai, atau Menyediakan Narkotika Golongan I dalam bentuk tanaman :

\section{Pasal $111(1)$ :}

Setiap orang yang tanpa hak atau melawan hukum menanam,memelihara,memiliki,me nyimpan,menguasai atau menyediakan narkotika golongan I dalam bentuk tanaman dipidana penjara paling singkat 4 tahun dan paling lama 12 tahun dan denda paling sedikit Rp 800 juta rupiah dan paling banyak Rp 8 miliar rupiah.

\section{Pasal $111(2)$ :}

Dalam hal perbuatan menanam, memelihara, menyimpan, menguasai, atau menyediakan narkotika golongan I dalam bentuk tanaman sebagaimana dimaksud dalam ayat(1) beratnya melebihi 1 kilogram atau melebihi 5 batang pohon ,pelaku dipidana penjara paling singkat 5 tahun dan paling lama 20 tahun dan pidana denda paling banyak Rp 8 miliar rupiah ditambah $1 / 3$

Sedangkan sanksi bagi orang yang tanpa hak atau melawan hukum memeiliki, menyimpan, menguasai, atau menyediakan Narkotioka bukan tanaman tercantum dalam pasal sebagai berikut :

1. Pasal 112 ayat(1) :

Setiap orang yang tanpa hak atau melawan hukum memiliki,menyimpan,menguasai atau menyediakan narkotika bukan tanaman dipidana penjara paling singkat 4 tahun dan paling lama 12 tahun dan denda paling sedikit Rp 800 juta rupiah dan paling banyak Rp 8 miliar rupiah.

2. Pasal 117 ayat (1) :

setiap orang yang tanpa hak atau melawan hukum memiliki,menyimpan,menguasai atau menyediakan narkotika golongan II dipidana penjara paling singkat 3 tahun dan paling lama 10 tahun dan pidana denda paling sedikit Rp 600 juta rupiah dan paling banyak Rp 5 miliar rupiah.'

3. Pasal 122 ayat (1):

setiap orang yang tanpa hak dan melawan hukum memiliki,menyimpan,menguasai atau menyediakan narkotika 
golongan III dipidana penjara paling singkat 2 tahun dan paling lama 7 tahun dan pidana denda paling sedikit Rp 400 juta rupiah dan paling banyak Rp 3 miliar rupiah

kemudian sanksi bagi orang yang menyimpan, menguasai, atau menyediakan Narkotika bukan tanaman, melebihi 5 (lima) gram tercantum dalam pasal sebgai berikut :

1. Pasal 112 ayat (2) :

Dalam hal perbuatan memiliki, menyimpan,menguasai, atau menyediakan narkotika golongan I bukan tanaman lebih dari 5 gram pelaku dipidana penjara paling singkat 5 tahun, dan paling lama 20 tahun dan pidana denda paling banyak Rp 8 miliar rupiah ditambah $1 / 3$.

2. Pasal 117 ayat (2) :

Dalam hal perbuatan memiliki, menyimpan,menguasai atau menyediakan narkotika golongan II yang beratnya melebihi 5

gram,pelaku dipidana penjara paling singkat 5 tahun dan paling lama 15 tahun dan pidana denda paling banyak Rp 5 miliar rupiah ditambah $1 / 3$.

3. Pasal 122 ayat (2) :

Dalam hal perbuatan memiliki,menyimpan,menguasai atau menyediakan narkotika golongan III beratnya melebihi 5 gram ,pelaku dipidana penjara paling singkat 3 tahun dan paling lama 10 tahun dan pidana dengan paling banyak Rp 3 miliar ditambah $1 / 3$
Dalam Undang-Undang Narkotika dijelaskan sanksi-sanki bagi yang memproduksi, mengimpor, mengekspor, atau menyalurkan narkotika sebagai berikut :

1. Pasal 113 ayat (1) :

Setiap orang yang tanpa hak atau melawan hukum memproduksi,mengimpor,mengeks por,atau menyalurkan narkotika golongan I dipidana penjara paling singkat 5 tahun dan paling lama 15 tahun dan pidana denda paling sedikit Rp 1 miliar rupiah dan paling banyak Rp 10 miliar rupiah.

2. Pasal 118 ayat (1) :

Setiap orang yang tanpa hak atau melawan hukum memproduksi,mengimpor,mengeks por atau menyalurkan narkotika golongan II dipidana penjara paling singkat 4 tahun dan paling lama 12 tahun,dan denda paling sedikit Rp 800 juta rupiah dan paling banyak Rp 8 miliar rupiah

3. Pasal 123 ayat(1):

Setiap orang yang tanpa hak atau melawan hukum memproduksi,mengimpor,mengeks por atau menyalurkan narkotika golongan III dipidana penjara paling singkat 3 tahun dan paling lama 10 tahun dan denda paling sedikit Rp 600 juta rupiah dan paling banyak Rp 5 miliar rupiah

Sanksi Terhadap Perantara Narkotika

untuk sanksi perantra narkotika itu sendiri belum dijelaskan secara kuhsus namun sudah ada di dalam pasal 114, 119, 124, dan 129 yakni sebagai berikut: 
1. Perantara dalam transaksi Narkotika Golongan I.

Setiap orang yang tanpa hak atau melawan hukum menawarkan untuk dijual, menjual, membeli, menerima, menjadi perantara dalam jual beli, menukar, atau menyerahkan Narkotika Golongan I, dipidana dengan pidana penjara seumur hidup atau pidana penjara paling singkat 5 (lima) tahun dan paling lama 20 (dua puluh) tahun dan pidana denda paling sedikit Rp. 1.000.000.000,00 (satu miliar rupiah) dan paling banyak $\mathrm{Rp}$. 10.000.000.000,00 (sepuluh miliar rupiah)." (Pasal 114 ayat [1] UU Narkotika)

2. Perantara dalam Jual Beli Narkotika Golongan I dalam Bentuk Tanaman yang Beratnya Melebihi 1 (satu) Kilogram atau Melebihi 5 (Lima) Batang Pohon atau dalam Bentuk Bukan Tanaman yang Beratnya Melebihi 5 (Lima) Gram.

Dalam hal perbuatan menawarkan untuk dijual, menjual, membeli, menjadi perantara dalam jual beli, menukar, menyerahkan, atau menerima Narkotika Golongan I sebagaimana dimaksud pada ayat (1) yang dalam bentuk tanaman beratnya melebihi 1 (satu) kilogram atau melebihi 5(lima) batang pohon atau dalam bentuk bukan tanaman beratnya 5 (lima) gram, pelaku dipidanadengan pidana mati, pidana penjara seumur hidup, atau pidana penjara paling singkat 6 (enam) tahun dan paling lama 20 (dua puluh) tahun dan pidana denda maksimum sebagaimana dimaksud pada ayat (1) ditambah $1 / 3$ (sepertiga). (Pasal 114 ayat [2] UU Narkotika)
3. Perantara dalam Jual Beli Narkotika Golongan II.

Setiap orang yang tanpa hak atau melawan hukum menawarkan untuk dijual, menjual, membeli, menerima, menjadi perantara dalam jual beli, menukar, atau menyerahkan Narkotika Golongan II, dipidana dengan pidana penjara paling singkat 4 (empat) tahun dan paling lama 12 (dua belas) tahun dan pidana denda paling sedikit Rp. 800.000.000,00 (delapan ratus juta rupiah) dan paling banyak $\mathrm{Rp}$. 8.000.000.000,00 (delapan miliar rupiah)." (Pasal 119 ayat [1] UU Narkotika)

4. Perantara dalam Jual Beli Narkotika Golongan II yang Beratnya Melebihi 5 (Lima) Gram.

Dalam hal perbuatan menawarkan untuk dijual, menjual, membeli, menerima, menjadi perantara dalam jual beli, menukar, atau menyerahkan Narkotika Golongan II sebagaimana dimaksud pada ayat (1) beratnya melebihi 5 (lima) gram, pelaku dipidana dengan pidana mati, pidana penjara seumur hidup, atau pidana penjara paling singkat 5 (lima) tahun dan paling lama 20 (dua puluh) tahun dan pidana denda maksimum sebagaimana dimaksud pada ayat (1) ditambah $1 / 3$ (sepertiga). (Pasal 119 ayat [2] UU Narkotika)

5. Perantara dalam Jual Beli Narkotika Golongan III

Setiap orang yang tanpa hak atau melawan hukum menawarkan untuk dijual, menjual, membeli, menerima, menjadi perantara dalam jual beli, menukar, atau menyerahkan Narkotika Golongan III, dipidana dengan pidana penjara paling singkat 3 (tiga) tahun dan paling lama 10 (sepuluh) tahun dan 
pidana denda paling sedikit $\mathrm{Rp}$. 600.000.000,00 (enam ratus juta rupiah) dan paling banyak Rp. 5.000.000.000,00 (lima miliar rupiah). (Pasal 124 ayat [1] UU Narkotika)

6. Perantara dalam Jual Beli Narkotika Golongan III yang Beratnya Melebihi 5 (Lima) Gram.

Dalam hal perbuatan menawarkan untuk dijual, menjual, membeli, menerima, menjadi perantara dalam jual beli, menukar, atau menyerahkan Narkotika Golongan III sebagaimana dimaksud pada ayat (1) beratnya melebihi 5 (lima) gram, pelaku dipidana dengan pidana penjara paling singkat 5 (lima) tahun dan paling lama 15 (lima belas) tahun dan pidana denda maksimum sebagaimana dimaksud pada ayat (1) ditambah 1/3 (sepertiga). (Pasal 124 ayat [2] UU Narkotika).

Selain ketentuan-ketentuan sanksi pidana bagi orang yang menjadi perantara transaksi narkotika tersebut, ada juga ketentuan bagi orang yang menjadi perantara transaksi prekursor narkotika. Prekursor narkotika adalah zat atau bahan pemula atau bahan kimia yang dapat digunakandalam pembuatan Narkotika (Pasal 1 angka 2 UU Narkotika).

Ketentuan pidana bagi perantara jual beli prekursor narkotika terdapat dalam Pasal 129 huruf cyang berbunyi:

Pasal 129:

Dipidana dengan pidana penjara paling singkat 4 (empat) tahun dan paling lama 20 (dua puluh) tahun dan denda paling banyak $\mathrm{Rp}$ 5.000.000.00,00 (lima miliar rupiah) setiap orang tanpa hak atau melawan hukum : menawarkan untuk dijual, menjual, membeli, menerima, menjadi perantara dalam jual beli, menukar, atau menyerahkan prekursor Narkotika untuk membuat Narkotika.

\section{C.Penutup}

\section{Kesimpulan}

Ketentuan hukum perantara tindak pidana narkotika hanya di atur dalam Undang Undang nomor 35 tahun 2009 dalam pasal 114, 119, 124, 129 yang berbunyi: Setiap orang yang tanpa hak atau melawan hukum menawarkan untuk dijual, menjual, memebeli, menerima, menjadi perantara dalam jual beli, menukar atau menyerahkan Narkotika golongan I,II,III

Sanksi hukum bagi perantara tindak pidana narkotika adalah hukuman penjara paling singkat 3 (tiga) tahun atau denda paling sedikit 600.000.000.000 (enam ratus jutah rupiah) dan hukuman penjara paling lama 20 (dua puluh) tahun atau denda 10.000.000.000.000 (sepuluh miliar rupiah), sesuai yang tecantum dalam Undang Undang Narkotika nomor 35 Tahun 2009 pasal 114, 119, 124, 129.

\section{Saran}

ketentuan hukum perantara narkotika seharusnya dibuat lebih jelas lagi atau dibrntuk Undang Undang yang khusus agar tidak di samakan dengan pengedar narkotik, karena banyak pelaku yang merasa terjebak menjadi perantara narkotika.

Untuk masyarakat umum lebih waspada dan berhati hati akan peredaran narkotika dan dengan pergaulan sesama teman agar tidak terjerumus sebagai perantara, kurir, bahkan Bandar narkotika karena sanksi yang sangat berat untuk menjerat para pelaku penyalahgunaan narkotika. 


\section{D.DAFTAR PUSTAKA}

\section{Literatur}

Alfi Fahmi,Sistem Pidana di Indonesia, PT. Akbar Pressindo, Surabaya, 2002 Andi Hamzah dan M. Solehudin, Suatu Tinjauan Ringkas Sistem Pemidanaan Di Indonesia, Akademik Pressindo, Jakarta, 1986 Bambang Sunggono, Metodologi Penelitian Hukum, PT Raja Grafindo Persada, Jakarta, 2007 DR. Andi Hamzah, S.H., Asas Asas Hukum Pidana edisi revisi 2008 Drs. Adami Chazawi, SH., Pelajaran Hukum Pidana Bagian I, PT RajaGrafindo Persada, jakarta Hari Sasangka, Narkotika dan Psikotropika, Mandar Maju, Bandung, 2003

Peter Mahmud Marzuki, Penelitian Hukum, Kencana Prenada Media Group, Jakarta, 2010

\section{Peraturan Perundang-Undangan}

Undang-Undang Dasar 1945

Referendum

Kitab Undang-Undang Hukum

Pidana (KUHP)

Undang-Undang Nomor 35 Tahun 2009 Tentang Narkotika Peraturan Pemerintah Nomor 40 tahun 2013 Tentang Pelaksanaan Undang-Undang nomor 35 tahun 2009

Internet http//m.hukumonline.com 